\title{
Effect of concentration and temperature on the thermal conductivity of frozen acerola pulp
}

\section{Efeito da concentração e temperatura sobre a condutividade térmica da polpa de acerola congelada}

\author{
Cristina Guimarães Pereira ${ }^{1 *}$; Tales Márcio de Oliveira Giarola ${ }^{1}$; \\ Heloísa Helena de Siqueira Elias²; Jaime Vilela Resende ${ }^{3}$
}

\begin{abstract}
The purpose of this work was the experimental determination of the thermal conductivity of acerola pulp at concentrations of $5.5,7.5,9.5,11.5$ and $13.5^{\circ}$ Brix and temperatures of $0,-5,-10,-15,-20$, -25 and $-30^{\circ} \mathrm{C}$. The methodology used involved a hot wire probe, and the experimental results were compared with values estimated by several theoretical models (series, parallel and Maxwell-Eucken models) to evaluate the error involved. We observed an influence both of the concentration and the temperature on the thermal conductivity of the pulp. An increase of the conductivity with a decrease in temperature and in the solids concentration was detected. We observed the greatest increases in the range of 0 to $-10{ }^{\circ} \mathrm{C}$. Linear and polynomial equations were adjusted for the direct determination of the thermal conductivity of the pulp in the range of temperature and concentration studied.
\end{abstract}

Key words: Frozen acerola pulp, thermal conductivity, hot wire probe, theoretical model

\section{Resumo}

\begin{abstract}
A finalidade deste trabalho foi a determinação experimental da condutividade térmica da polpa de acerola nas concentrações de 5.5, 7.5, 9.5, 11.5 e $13.5^{\circ}$ Brix e nas temperaturas de $0,-5,-10,-15,-20,-25$ e -30 ${ }^{\circ} \mathrm{C}$. A metodologia utilizada foi a da sonda linear de aquecimento e os resultados experimentais obtidos foram comparados com valores estimados pelos modelos teóricos em série, paralelo e Maxwell-Eucken, avaliando o erro envolvido. Observou-se uma influência tanto da concentração quanto da temperatura na condutividade térmica da polpa. Houve aumento da condutividade com a redução da temperatura e da concentração de sólidos, observando-se os maiores aumentos na faixa de 0 a $-10{ }^{\circ} \mathrm{C}$. Equações polinomiais e lineares foram ajustadas para a determinação direta da condutividade térmica da polpa de acerola na faixa de temperatura e concentração estudada.

Palavras-chave: Polpa congelada de acerola, condutividade térmica, sonda de fio quente, modelo teórico
\end{abstract}

\footnotetext{
1 Discentes de Doutorado Ciência dos Alimentos, Universidade Federal de Lavras, UGLA, Lavras, MG, Brasil. E-mail: crisgp13@ yahoo.com.br; tgiarola@dca.ufla.br ${ }^{3}$

2 Pós-doutoranda Ciência dos Alimentos, UFLA, Lavras, MG, Brasil. E-mail: heloisa.elias@yahoo.com.br

3 Prof. Dr. em Engenharia de Alimentos, UFLA, Lavras, MG, Brasil. E-mail: jvresende@dca.ufla.br

Author for correspondence
} 


\section{Introduction}

Acerola (Malpighia spp.), also called cherry Antilles, is a tropical tree that produces fruit very rich in vitamin C (MANICA et al., 2003). In Brazil, it is planted in all regions, but Pernambuco, Ceará, São Paulo and Bahia are the main producers (RITZINGER et al., 2003). The agribusiness sector is a major stimulator of acerola planting in Brazil. Acerola is a climacteric fruit and is highly perishable, so it requires an agile commercialization process. In the domestic market, its consumption occurs in fresh or processed form, such as juices, pulps, jams, ice creams, syrups, liqueurs and candy syrups. For the export market, which consumes $80 \%$ of the Brazilian production, the fruit pulp and fruit are exported frozen, both in the green and ripe states. Japan is the major importer of Brazilian acerola and is also the intermediary of distribution for Europe (RITZINGER et al., 2003).

For the processing of acerola, there is a need to apply thermal processes involving heat transfer, including heating, cooling and freezing. Knowledge of thermophysical properties then becomes essential for the optimization and design of the equipment used in processes involving heat transfer (MERCALI et al., 2011). A large amount of data has been published in the literature, but for tropical fruit pulps, data are still scarce (PEREIRA et al., 2013; RENO et al., 2011; AZOUBEL et al., 2005). At low temperatures, the measurements are quite difficult to perform due to the dependence of the properties on the continual change of the content of ice in the temperature range between 0 and $-40{ }^{\circ} \mathrm{C}$ and the large variations in these properties (RENAUD et al., 1992). According to Ashrae (2002), the ice fraction produced during the freezing of food greatly affects its thermophysical properties because the conductivity of the ice is four times that of liquid water. Thus, it is necessary to obtain accurate data for the thermophysical properties and to accurately predict the behavior of these properties during processing as a function of temperature and concentration (BECKER; FRICKE, 1999).
Among the thermophysical properties, the thermal conductivity is considered the most influential during heat processing and is highly dependent on the composition and temperature of the food. The transient method of the hot wire probe has emerged as the most widely used method to measure the thermal conductivity, and its popularity is due to its relative simplicity and relatively short measurement times (CARSON, 2006). The measurement is based on applying a constant heat flux from the heat source for the material, initially in equilibrium, which generates a variation in temperature of $T_{\mathrm{o}}$ to $T$. This increase is expressed by equation 1 (AZOUBEL et al., 2005). The probe radius was considered infinitely small compared to the surrounding medium in which it was inserted.

$$
\mathbf{\Delta} T=T-T_{o}=\frac{q}{\mathbf{4} \pi k}\left[\ln \left(\frac{t}{t_{o}}\right)\right]
$$

where:

$\Delta T$ - temperature difference $(\mathrm{K})$;

$q$ - power per linear meter $\left(\mathrm{W} \mathrm{m}^{-1}\right)$;

$k$ - thermal conductivity $\left(\mathrm{W} \mathrm{m}^{-1} \mathrm{~K}^{-1}\right)$;

$t$ - time (s).

To determine the heating power generated by the source (equation 2), the data from the resistance heating unit (nickel/chrome) inside the probe and the current supplied by the heating source were used.

$$
q=R \cdot i^{2}
$$

where:

$q$ - power per linear meter $\left(\mathrm{W} \mathrm{m}^{-1}\right)$;

$R$ - electrical resistance $\left(\Omega \mathrm{m}^{-1}\right)$;

$i$ - electrical current (A) 
Equation 1 illustrates the relationship between the thermal conductivity and the temperature difference $\left(T-T_{0}\right)$. The linear correlation of this difference and $\ln \left(\frac{t}{t_{0}}\right)$ is given by slope $(m)$, as calculated by equation 3 (BROCK et al., 2008).

$$
m=\frac{q}{4 \pi k}
$$

where:

$m$-slope;

$q$ - power per meter $\left(\mathrm{W} \mathrm{m}^{-1}\right)$;

$k$ - thermal conductivity $\left(\mathrm{W} \mathrm{m}^{-1} \mathrm{~K}^{-1}\right)$.

Thus, the thermal conductivity shown in equation 4 may be obtained from the slope of equation 3 .

$$
k=\frac{q}{\mathbf{4} \pi m}
$$

The aim of this study was to determine experimentally, using the hot wire probe method, the values of the thermal conductivity of the pulp as a function of concentration and temperature. These experimental data were then compared with values obtained from mathematical models found in the literature, such as parallel, series and MaxwellEucken models, and the experimental errors involved were calculated.

\section{Material and Methods}

Sample

Acerola was purchased on the local market of Lavras-MG. The separation of the pulp was performed with an electric depulper (Macanuda, Joinville, Santa Catarina), yielding a pulp with 7.5 ${ }^{\circ}$ Brix. A portion of the sample was removed and diluted to $5.5^{\circ}$ Brix, and the other portion was dried in a freeze-dryer (Edwards High Vacuum - Model - L4KR). The pulp was removed after 34 hours before it was fully freeze-dried. After the freezedrying, a product was obtained with an approximate concentration from 14.0 to $15.0{ }^{\circ}$ Brix. These concentrations were adjusted to $9.5,11.5$ and 13.5 ${ }^{\circ}$ Brix by adding distilled water. The determination of soluble solids was performed by direct reading on a hand-held refractometer (Atago - N1, Tokyo, Japan). Subsequently, a proximate characterization of the pulp was performed at different concentrations. The amount of moisture, protein, fiber and ash were determined according to the methodology of the Association of Official Analytical Chemists (1996), and the fat content was determined according to the methodology of the Instituto Adolfo Lutz (2008). Carbohydrates were determined by the difference between the total $(100 \%)$ and the percentage of moisture, protein, fat, fiber and ash.

\section{Construction and calibration of the probe}

The probe was constructed with a hypodermic needle with a $0.6 \mathrm{~mm}$ external diameter that was 70 $\mathrm{mm}$ in length, into which was placed a resistance heating wire $(21,325 \Omega / \mathrm{m}$ - Omega Engineering Inc., Stamford, CT, USA) with a $0.36 \mathrm{~m}$ length and $0.08 \mathrm{~mm}$ diameter, together with a small thermocouple type T, AWG 30 (Omega Engineering Inc.) located in the exact center of the probe. These components were insulated with epoxy resin.

The probe was calibrated for temperature and thermal conductivity. Apart from the calibration with temperature, the probe was calibrated using a $10 \%$ model solution of sucrose $(99.8 \%$, Isofar, Duque de Caxias, Brazil; $0.1 \mathrm{~g} \mathrm{~mL}^{-1}$ of solution). Its conductivity was determined under the same conditions as used in the pulp and then compared with theoretical values from the literature. The values were $1.81,1.78,1.74,1.71$ and $1.65 \mathrm{~W}$ $\mathrm{m}^{-1} \mathrm{~K}^{-1}$ for the thermal conductivity of $10 \%$ sucrose at temperatures of $-30,-25,-20,-15$ and $-10{ }^{\circ} \mathrm{C}$, respectively (RENAUD et al., 1992). According to Pereira et al. (2013), with a calibrated probe, it is possible to determine a correction factor $f$, as shown in equation 5. 


$$
f=\frac{k_{\text {theoretical }}}{k_{\text {experimental }}}
$$

\section{Initial Freezing Temperature}

Data from the initial freezing temperature $\left(\mathrm{T}_{\mathrm{f}}\right)$ were used to evaluate the ice fraction present at each analysis temperature. The $\mathrm{T}_{\mathrm{f}}$ was evaluated directly from the cooling curve obtained from the temperature drop as a function of time during the freezing of the pulp. Measurements were performed in triplicate.

For data acquisition, a thermocouple type $\mathrm{T}$ AWG 30 (Omega Engineering Inc., Stamford, CT, USA) was used. The thermocouple was inserted into the center of the beaker with the sample.

For the cooling, an ultra thermostatic bath (model 521/3DE; Nova Ética, Vargem Grande Paulista, Brazil) with digital temperature control was used. The temperature data were recorded through a signal conditioning system (National Instruments Mod. SCXI; Budapest, Hungary). The temperature record was made in intervals of 1.0 second using LabView 8.5 software (National Instruments, Newbury, Ireland). First, the bath was adjusted to $-5^{\circ} \mathrm{C}$, and when the pulp inside reached $5{ }^{\circ} \mathrm{C}$, data acquisition was initiated. When the sample temperature reached $0{ }^{\circ} \mathrm{C}$, the bath had its temperature lowered to $-10{ }^{\circ} \mathrm{C}$, and after detection of the initial freezing temperature, the bath was set at $-15{ }^{\circ} \mathrm{C}$. This gradual lowering of the temperature of the bath was carried out to detect subcooling and thus make the $\mathrm{T}_{\mathrm{f}}$ value more obvious.

\section{Determination of experimental thermal conductivity}

The determination of the thermal conductivity of the pulp was carried out as shown in Figure 1. To stabilize and maintain the samples at low temperatures, a cooling system was developing using an alcoholic solution (ethanol $60{ }^{\circ} \mathrm{GL}$ ) and an ultra thermostatic bath (model 521/3DE; Nova Ética, Vargem Grande Paulista, Brazil) with digital temperature control. Samples of the pulp were placed in $250 \mathrm{~mL}$ glass beakers and these beakers were then immersed in the bath.

The probe was inserted into the geometric center of the pulp sample that was at a uniform temperature inside the ultra thermostatic bath. When the internal temperature of the pulp (measured by thermocouple) was $\mathrm{T} \pm 1^{\circ} \mathrm{C}$, the probe was subjected to a constant heating output $\left(3.412 \mathrm{~W} \mathrm{~m}^{-1}\right)$ supplied by the current source $(0.4 \mathrm{~A})$. The power application generated a temperature rise inside the pulp, which was recorded through the signal conditioning system.

Figure 1. Experimental setup of the hot wire probe for determining the thermal conductivity of the pulps: 1) Sample, 2) Probe heating, 3) Ultra thermostatic bath, 4) Current source, 5) Signal conditioning system, 6) Microcomputer, 7) Ammeter, A) Constantan wire, B) Copper wire, C and D) Feeder of the probe resistance.

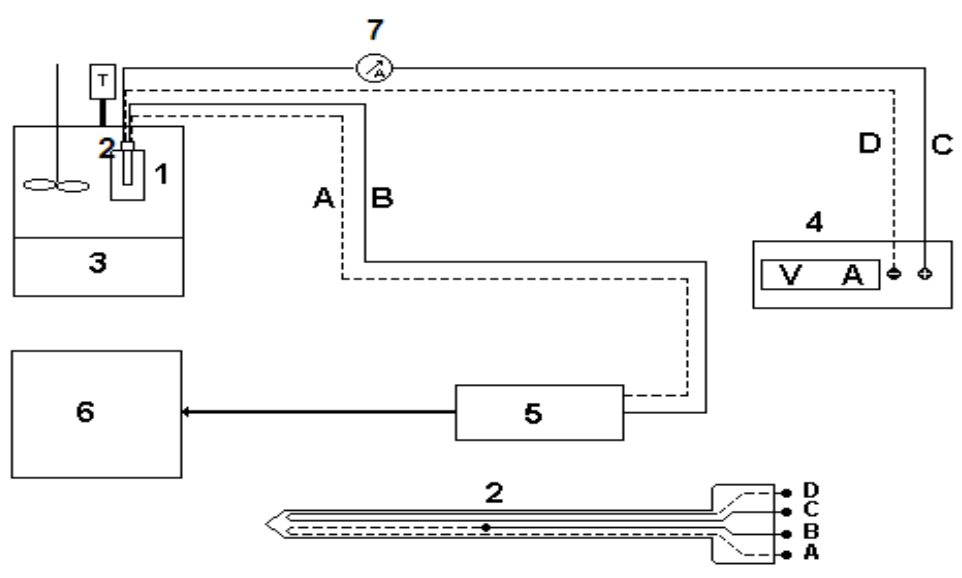


Using the data for the temperature and heating time of the sample, the slope $m$ was obtained (equation 3) from the linear part of the experimental curve temperature vs. the natural logarithm of time. The temperature record was made in intervals of 1.0 second and the values of thermal conductivity were measured in triplicate.

Theoretical models for predicting the thermal conductivity

The theoretical models used to predict the thermal conductivity of the pulp were the parallel, series and Maxwell-Eucken models, as shown in Figure 2 in equations 6,7 and 8, respectively.

$k_{p a}$ is the parallel thermal conductivity ( $\mathrm{W} \mathrm{m}^{-1} \mathrm{~K}^{-}$ $\left.{ }^{1}\right), k_{s e}$ is the perpendicular thermal conductivity (W $\left.\mathrm{m}^{-1} \mathrm{~K}^{-1}\right), k_{m e}$ is Maxwell-Eucken thermal conductivity $\left(\mathrm{W} \mathrm{m}^{-1} \mathrm{~K}^{-1}\right.$ ), $i$ indicates the pure component (protein, ash, fiber, carbohydrate, fat and water), $n$ is the number of components, $c$ indicates the continuous phase, $d$ indicates the dispersed phase, and $q$ is the heating power per meter $\left(\mathrm{W} \mathrm{m}^{-1}\right)$.

The volumetric fractions of each component were determined by equation 9 .

$$
X_{i}^{v}=\frac{\frac{x_{i}}{\rho_{i}}}{\sum \frac{x_{i}}{\rho_{i}}}
$$

Where $X_{i}^{v}$ is the volumetric fraction, $x_{i}$ is the mass fraction of each component, $\rho_{i}$ the density $(\mathrm{kg}$ $\left.\mathrm{m}^{-3}\right)$, and $\sum X_{i}=1$.

Figure 2. Structural models for the determination of the thermal conductivity.

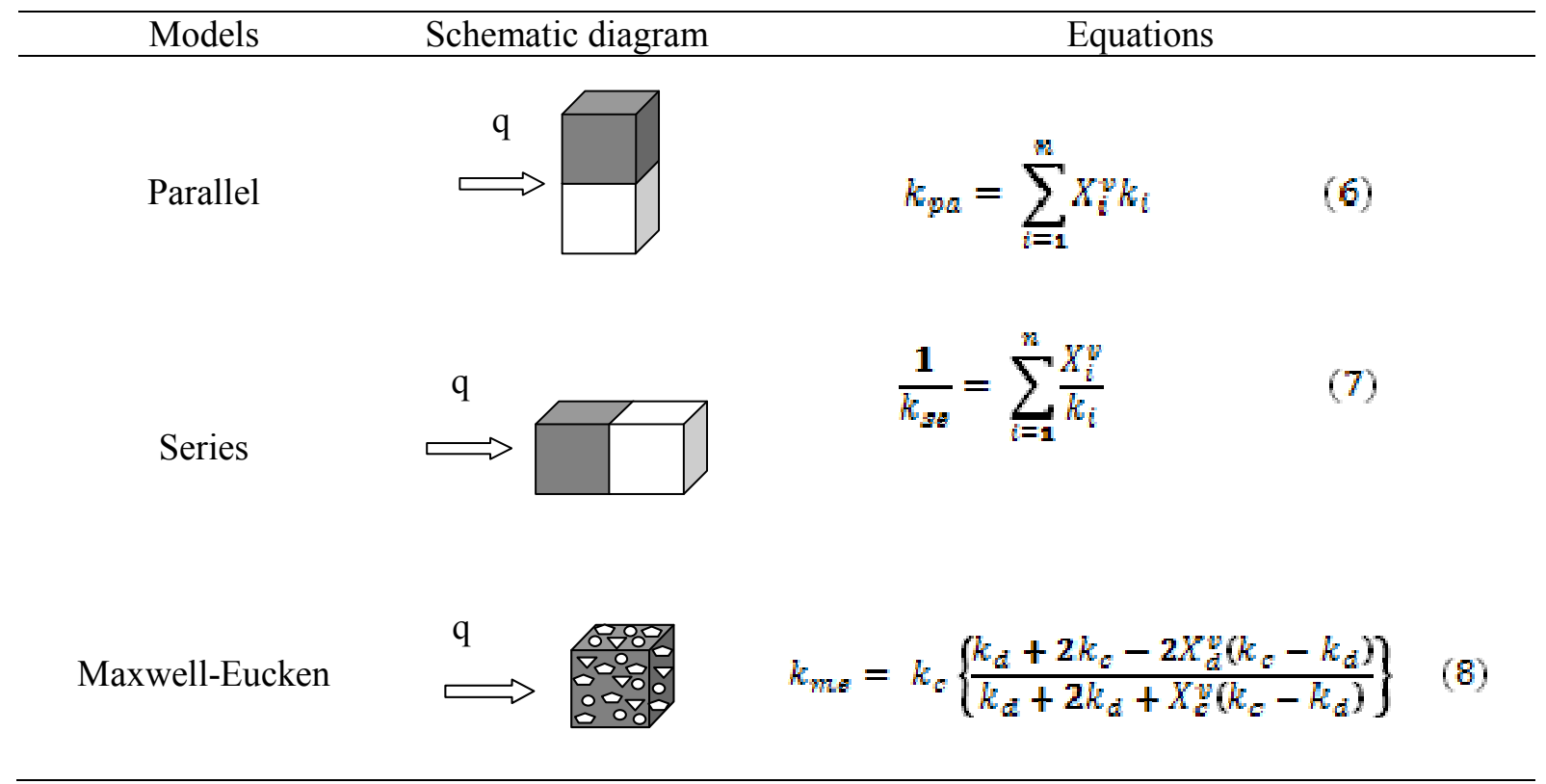

Source: Miyawaki and Pongsawatmanit (1994).

The equations used for determining the density and thermal conductivity of the pure components are presented in Tables 1 and 2, respectively.
To determine the molar fractions of ice at each temperature, equations 10 and 11 proposed by Heldman and Lund (1992) were used. 


$$
\ln X_{w o}(T)=\frac{L}{\mathbf{R}}\left(\frac{\mathbf{1}}{T_{\mathrm{f} w}}-\frac{\mathbf{1}}{T}\right) \quad T \leq T_{\mathrm{f} S}
$$

where:

$X_{\text {wo }}$ - molar fraction of unfrozen water;

$T_{\mathbf{f S}}$ - freezing initiation temperature of the food $(\mathrm{K})$;

$T_{\mathbf{f} w}-$ initial freezing of water $(273.15 \mathrm{~K})$;

$T$ - temperature of the food $(\mathrm{K})$;

$\mathrm{R}$ - universal gas constant $\left(8.314 \mathrm{~kJ} \mathrm{~kg}^{-1} \mathrm{~mol}^{-1} \mathrm{~K}^{-1}\right)$;

$L$ - latent heat of fusion of water $\left(333.6 \mathrm{~kJ} \mathrm{~kg}^{-1}\right)$.

$$
X_{w o}(T)=\frac{\frac{\mathbf{m}_{w o}(T)}{M_{w}}}{\frac{\mathbf{m}_{w o}(T)}{M_{w}}+\frac{\mathbf{m}_{s}}{M_{s}}}
$$

Where $\mathrm{m}_{w o}(T)$ is the mass of water that does not freeze at the temperature $(T), \mathrm{m}_{s}$ is the mass of the solids, and $M_{w}$ and $M_{S}$ are the molecular weights of water and solids, respectively.

Thus, if the freezing initiation temperature of the food is known ( $\left.T_{\mathrm{fS}}\right)$, by substituting $T$ for $T_{\mathrm{fS}}$ in equation 10, the effective molecular weight of solids $\left(\mathrm{M}_{\mathrm{s}}\right)$ can be determined by substituting equation 10 into 11. Then, the fraction of unfrozen water at a temperature $T$ of analysis can be determined by equation 10 , and substituting the result into equation 11 determines the mass of unfrozen water. The ice mass is then determined by the difference between the total mass of water and the mass of unfrozen water at the temperature $T$.

\begin{tabular}{|c|c|}
\hline Components & Thermal conductivity $(\mathrm{W} / \mathrm{mK})$ \\
\hline Protein & $k=1.7881 \times 10^{-1}+1.1958 \times 10^{-3} T-2.7178 \times 10^{-6} T^{2}$ \\
\hline Fat & $k=1.8071 \times 10^{-1}-2.7604 \times 10^{-3} T-1.7749 \times 10^{-7} T^{2}$ \\
\hline Carbohydrate & $k=2.0141 \times 10^{-1}+1.3874 \times 10^{-3} \mathrm{~T}-4.3312 \times 10^{-6} \mathrm{~T}^{2}$ \\
\hline Fiber & $k=1.8331 \times 10^{-1}+1.2497 \times 10^{-3} \mathrm{~T}-3.1683 \times 10^{-6} \mathrm{~T}^{2}$ \\
\hline Ash & $k=3.2962 \times 10^{-1}+1.4011 \times 10^{-3} \mathrm{~T}-2.9069 \times 10^{-6} \mathrm{~T}^{2}$ \\
\hline Water & $k=5.7109 \times 10^{-1}+1.7625 \times 10^{-3} \mathrm{~T}-6.7036 \times 10^{-6} \mathrm{~T}^{2}$ \\
\hline Ice & $k=2.2196-6.2489 \times 10^{-3} T+1.0154 \times 10^{-4} T^{2}$ \\
\hline
\end{tabular}

Table 1. Equations for the thermal conductivity of food components $\left(-40^{\circ} \mathrm{C} \leq T \leq 150{ }^{\circ} \mathrm{C}\right)$.

\begin{tabular}{|c|c|}
\hline Components & Density $\left(\mathrm{kg} / \mathrm{m}^{3}\right)$ \\
\hline Protein & $\rho=1.3299 \times 10^{3}-5.1840 \times 10^{-1} \mathrm{~T}$ \\
\hline Fat & $\rho=9.2559 \times 10^{2}-4.1757 \times 10^{-1} \mathrm{~T}$ \\
\hline Carbohydrate & $\rho=1.5991 \times 10^{3}-3.1046 \times 10^{-1} \mathrm{~T}$ \\
\hline Fiber & $\rho=1.3115 \times 10^{3}-3.6589 \times 10^{-1} \mathrm{~T}$ \\
\hline Ash & $\rho=2.4238 \times 10^{3}-2.8063 \times 10^{-1} \mathrm{~T}$ \\
\hline Water & $\rho=9.9718 \times 10^{2}+3.1439 \times 10^{-3} T-3.7574 \times 10^{-3} T^{2}$ \\
\hline Ice & $\rho=9.1689 \times 10^{2}-1.3071 \times 10^{-1} \mathrm{~T}$ \\
\hline
\end{tabular}

Table 2. Equations for density of food components $\left(-40^{\circ} \mathrm{C} \leq T \leq 150^{\circ} \mathrm{C}\right)$.

Source: (ASHRAE, 2002) 
The percentage error between the experimental thermal conductivity data and the thermal conductivity values produced by the theoretical models were calculated by using equation 12 .

$\operatorname{Erro}(\%)=\left|\frac{\left(k_{\text {experimental }}-k_{\text {theoretical }}\right)}{k_{\text {theoretical }}}\right| \times 100$

\section{Results and Discussion}

Physicochemical analysis of the pulp

Table 3 shows the chemical composition of the pulp at concentrations of $5.5,7.5,9.5,11.5$ and 13.5 ${ }^{\circ}$ Brix.

Table 3. Chemical composition and standard deviation (SD) of different concentrations of the pulp.

\begin{tabular}{cccccc}
\hline \multirow{2}{*}{ Item $(\%)$} & 5.5 & 7.5 & 9.5 & 11.5 & 13.5 \\
\cline { 2 - 5 } & 94.077 & 92.102 & 90.113 & 87.949 & 85.624 \\
Moisture & $(0.0038)$ & $(0.0153)$ & $(0.0198)$ & $(0.0120)$ & $(0.0946)$ \\
& 0.744 & 0.992 & 1.242 & 1.513 & 1.805 \\
Proteins & $(0.0161)$ & $(0.0215)$ & $(0.0269)$ & $(0.0328)$ & $(0.0391)$ \\
& 0.074 & 0.099 & 0.124 & 0.151 & 0.180 \\
Fats & $(0.0219)$ & $(0.0292)$ & $(0.0366)$ & $(0.0446)$ & $(0.0532)$ \\
& 4.336 & 5.729 & 7.183 & 8.754 & 10.455 \\
Carbohydrates & $(0.0165)$ & $(0.0304)$ & $(0.0316)$ & $(0.0313)$ & $(0.0515)$ \\
& 0.541 & 0.752 & 0.902 & 1.100 & 1.312 \\
Fibers & $(0.0428)$ & $(0.0570)$ & $(0.0714)$ & $(0.0870)$ & $(0.1038)$ \\
& 0.228 & 0.325 & 0.436 & 0.532 & 0.623 \\
Ash & $(0.0141)$ & $(0.0594)$ & $(0.0349)$ & $(0.0112)$ & $(0.0183)$ \\
\hline
\end{tabular}

Initial freezing temperature and frozen water fraction

Figure 3 shows the dynamic freezing of the pulp at concentrations of $5.5,9.5$ and $13.5^{\circ}$ Brix.

Undercooling was observed for all concentrations, facilitating the visualization of the initial freezing temperature at the beginning of the plateau of nearly constant temperature. It was observed that the most concentrated pulp had a lower undercooling. According to Rahman (2009), there are many factors involved in the tendency of a system to present subcooling, including temperature, cooling rate, and the volume and the amount of solute. The higher the concentration, the lower the undercooling for two reasons: faster nucleation initiation and a lower initial freezing temperature.

The initial freezing temperatures measures were $-0.9,-1.1,-1.4,-1.7$ and $-2.0{ }^{\circ} \mathrm{C}$ for the concentration $5.5,7.5,9.5,11.5$ and $13.5^{\circ}$ Brix, respectively. There was a decrease in the $T_{f}$ as a function of the increasing concentration of solids in the pulp. This drop at initial freezing temperature is caused by an increased concentration of solids in the unfrozen phase, which occurs due to the process of concentration and separation of water in the form of ice during freezing. With an increasing concentration of the pulp, there is an increase of nonvolatile solute, which reduces the partial vapor pressure of water. Then, the balance between the liquid and solid phase can only be achieved through a temperature reduction, resulting in a cryoscopic lowering (RAHMAN, 2009).

Figure 4 shows the increase in the mass fraction of ice as a function of freezing pulp with different concentrations. For the same temperature, the ice fraction of the more concentrated pulp is always lower than the specimens with a higher moisture content. 
Figure 3. Kinetics of freezing the pulp at concentrations of 5.5, 9.5 and $13.5^{\circ}$ Brix.

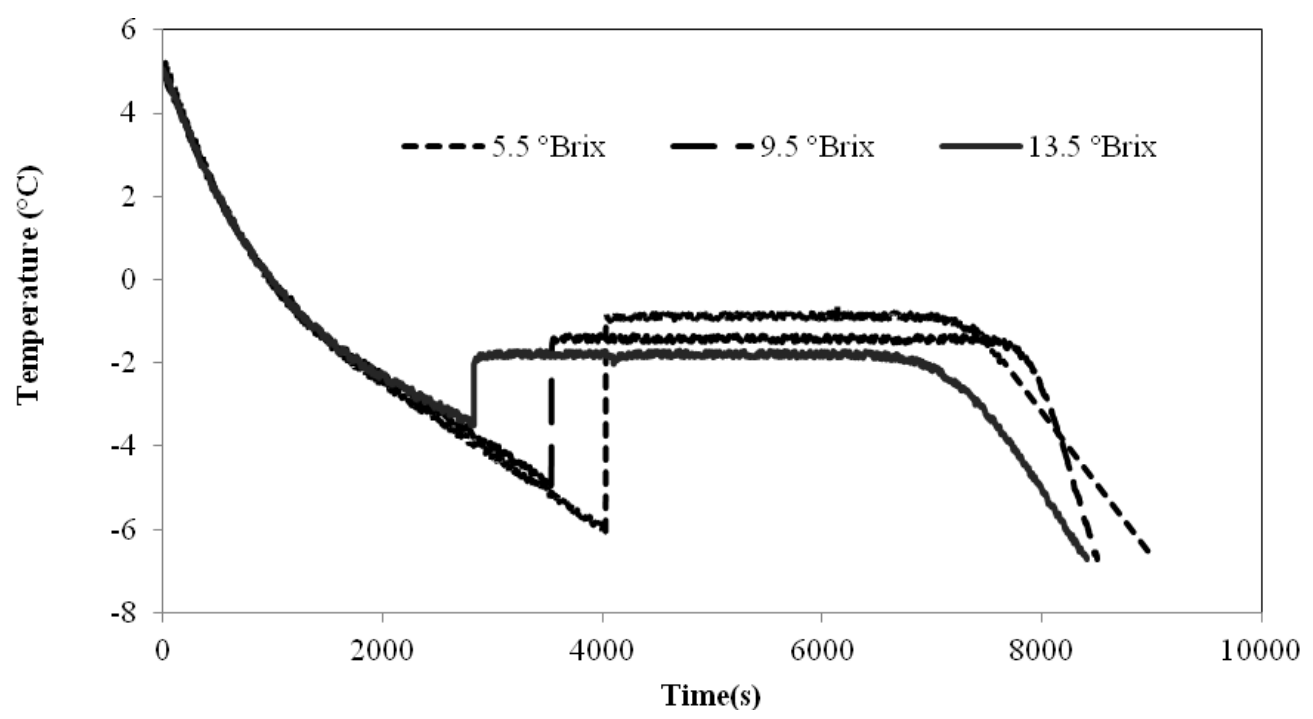

Figure 4. Increases in the mass fraction of ice for different concentrations of pulp in the range of 0 to $-30{ }^{\circ} \mathrm{C}$.

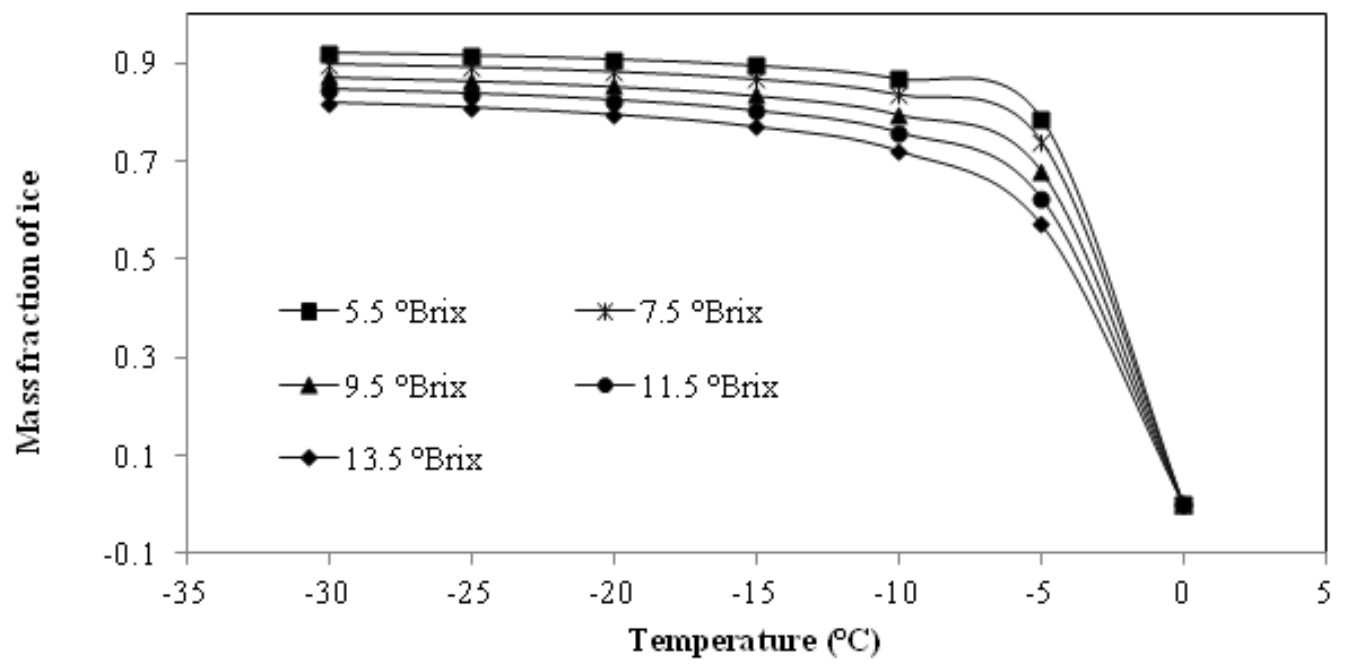

Figure 4 shows that in the range 0 to $-5^{\circ} \mathrm{C}$ for all concentrations of the pulp, there was a sudden increase in the mass fraction of ice. Afterward, -5 ${ }^{\circ} \mathrm{C}$ increases were still observed, but these increases were always smaller. In relation to the different concentrations, for all temperatures, it was observed that the most concentrated pulp had a lower mass fraction of ice in relation to the diluted pulp. This behavior is justified by the fact that the pulp with a lower solids concentration resulted in an initial higher freezing temperature $\left(-0.9^{\circ} \mathrm{C}\right)$. For the most concentrated pulp, by having a lower $\mathrm{T}_{\mathrm{f}}\left(-2^{\circ} \mathrm{C}\right)$ due to the lower presence of free water and higher solute concentration, the mobility of water molecules was reduced. This mobility is related to a higher solution viscosity, which complicates the increases in the number of ice crystals.

Figure 5 shows the percent gain in ice mass fraction for each decrease of $-5{ }^{\circ} \mathrm{C}$ over the range of 0 to $-30{ }^{\circ} \mathrm{C}$. 
Figure 5. Increase in the percentage of ice in the pulp during the decreases in temperature from $0{ }^{\circ} \mathrm{C}$ to $-30{ }^{\circ} \mathrm{C}$. Each of the ranges corresponds to a decrease of $-5^{\circ} \mathrm{C}$.

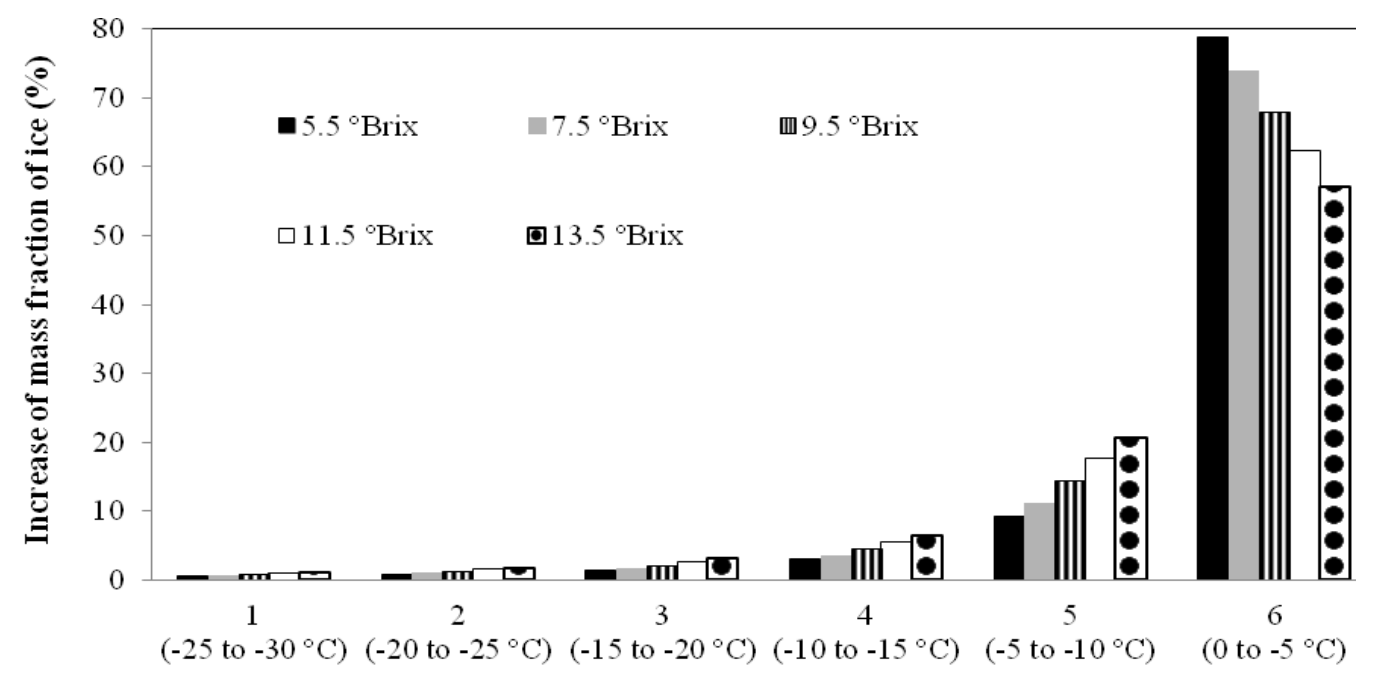

Temperature ranges $\left({ }^{\circ} \mathrm{C}\right)$

Figure 5 also shows that there was a sudden increase in the percentage of formation of ice in the range 0 to $-5{ }^{\circ} \mathrm{C}$. In this temperature range, for less concentrated pulp $\left(5.5^{\circ} \mathrm{Brix}\right)$, there was a greater percentage of ice formation than for more concentrated pulps. In other intervals, the highest percentage of ice formation was observed for the more concentrated pulps. This behavior can be justified by the fact that the more dilute pulp began to freeze before the others, such that for the first range $\left(0\right.$ to $\left.-5^{\circ} \mathrm{C}\right)$, it always has a higher percentage of its water in frozen form. For the next temperature decrease $\left(-5\right.$ to $\left.-30{ }^{\circ} \mathrm{C}\right)$, liquid water remaining in the pulp will contribute less to increasing the percentage of ice. For each temperature separately, this behavior can be explained by the amount of water available for freezing. The water available is always present in larger amounts in the most concentrated pulps because they have a lower initial freezing temperature.

Calibration of the probe with 10\% sucrose solution and determination of factor $f$

Table 4 shows the experimental results of the thermal conductivity of the $10 \%$ sucrose solution as a function of temperature. Factor $f$ is presented, which was subsequently used to correct the experimental thermal conductivities of the acerola pulp.

Table 4. Experimental thermal conductivities of the $10 \%$ sucrose solution, standard deviations, and correction factor $f$.

\begin{tabular}{cccc}
\hline Temperature $\left({ }^{\circ} \mathrm{C}\right)$ & Slope $(m)$ & Thermal conductivity $(\mathrm{W} / \mathrm{mK})$ & Factor $f$ \\
\hline-30 & 0.425 & $0.640(0.035)$ & 2.830 \\
-25 & 0.432 & $0.629(0.029)$ & 2.832 \\
-20 & 0.442 & $0.615(0.014)$ & 2.829 \\
-15 & 0.451 & $0.602(0.015)$ & 2.840 \\
-10 & 0.468 & $0.580(0.019)$ & 2.846 \\
\hline
\end{tabular}


With the calibration, a correction factor average of 2.836 was obtained.

\section{Thermal conductivity of the acerola pulp}

Figure 6 shows the behavior of the experimental thermal conductivity versus temperature for the concentration of pulp from 5.5 to $13.5^{\circ}$ Brix and an exponential model adjusted for each concentration.

The behavior of the curves presented in Figure 6 is compatible with those shown by Heldman
(1982) because the thermal conductivity of the pulp increased with a decrease in temperature, which demonstrates the dependency between these two factors.

For all concentrations, a sudden increase in conductivity in the temperature range of 0 to -10 ${ }^{\circ} \mathrm{C}$ was observed due to the strong variations in the ice fraction in this range, which affect the thermal conductivity of frozen materials because the conductivity of the ice is four times that of liquid water (RENAUD et al., 1992).

Figure 6. Exponential model and experimental thermal conductivities of the acerola pulp at concentrations of 5.5, 7.5, 9.5, 11.5 and $13.5^{\circ}$ Brix for the temperature range of 0 to $-30^{\circ} \mathrm{C}$.

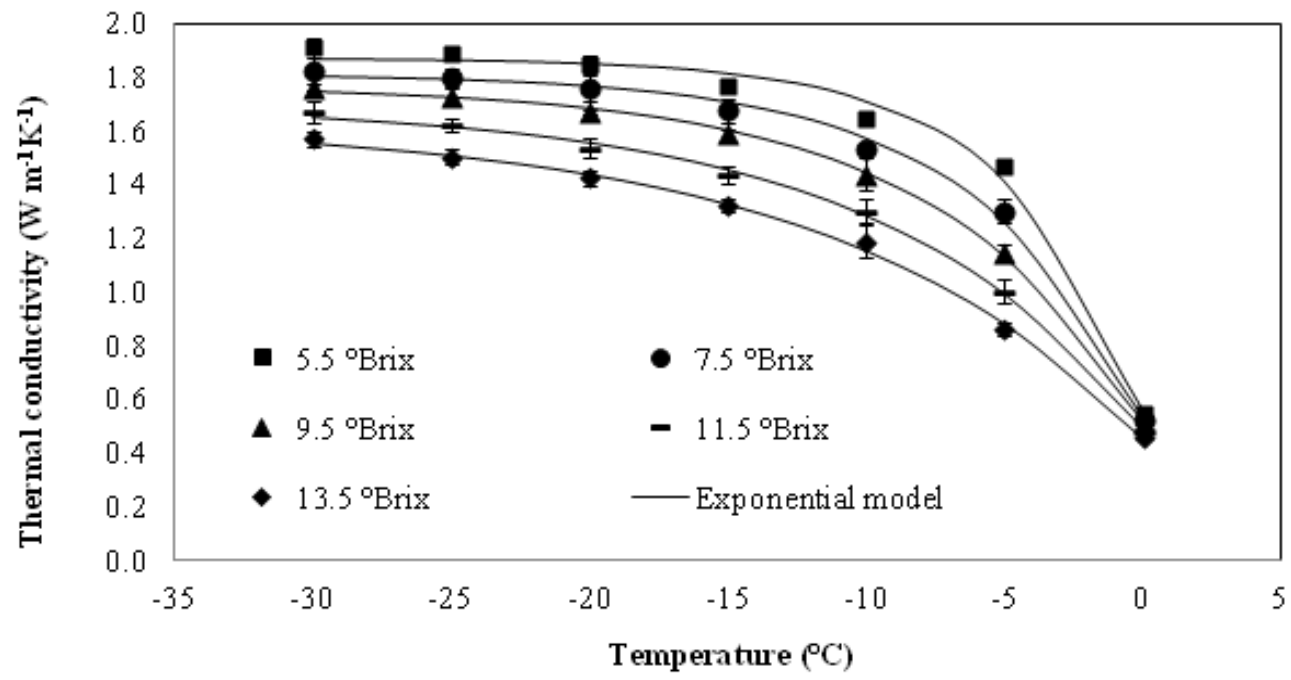

For pulps with a higher percentage of water, it was observed that the thermal conductivity was always higher than that of less concentrated pulp at the same temperature. A similar result was also observed by Azoubel et al. (2005) in a study with cashew juice in the concentration range from 5.5 to $25^{\circ}$ Brix. They observed that there was a strong dependence of conductivity on concentration, with a notable decrease in conductivity as the concentration increased.
The experimental results presented in Figure 6 were fitted with exponential equations for the direct determination of the thermal conductivity of the pulp at concentrations of 5.5, 7.5, 9.5, 11.5 and 13.5 ${ }^{\circ}$ Brix and over the temperature range of 0 to $-30{ }^{\circ} \mathrm{C}$, as shown in Table 5. 
Table 5. Equations for assessing the thermal conductivity of the acerola pulp in the temperature range of 0 to $-30^{\circ} \mathrm{C}$.

\begin{tabular}{ccc}
\hline Concentration $\left({ }^{\circ}\right.$ Brix $)$ & Equations $\left(-3 \mathbf{0}^{\circ} \mathrm{C} \leq T \leq \mathbf{0}^{\circ} \mathrm{C}\right)$ & $\mathrm{R}^{2}$ \\
\hline 5.5 & $k=-1.31 \mathbf{3} e^{\left(\frac{T}{4.771}\right)}+1.871$ & 0.987 \\
7.5 & $k=-1.274 e^{\left(\frac{T}{5.982}\right)}+1.807$ & 0.994 \\
9.5 & $k=-1.253 e^{\left(\frac{T}{7.416}\right)}+1.767$ & 0.999 \\
11.5 & $k=-1208 e^{\left(\frac{T}{9.384}\right)}+1.700$ & 0.997 \\
13.5 & $k=-1.181 e^{\left(\frac{T}{11.11 \mathrm{a}}\right)}+1.635$ & 0.997 \\
\hline
\end{tabular}

where: $k$ - thermal conductivity $\left(\mathrm{Wm}^{-1} \mathrm{~K}^{-1}\right) ; T$ - temperature $\left({ }^{\circ} \mathrm{C}\right)$.

For a better understanding of the thermal conductivity and evaluation of the influence of the concentration of the pulp and the percentage mass fraction of ice, the increase in thermal conductivity was evaluated in terms of percentages for the various concentrations of the pulp and for each -5 ${ }^{\circ} \mathrm{C}$ temperature drop in the range of 0 to $-30{ }^{\circ} \mathrm{C}$. Figure 7 shows the behavior exhibited.

Figure 7. Increase of the thermal conductivity in percentage terms during the decrease from $0{ }^{\circ} \mathrm{C}$ to $-30{ }^{\circ} \mathrm{C}$. Each of the ranges corresponds to a decrease of $-5^{\circ} \mathrm{C}$.

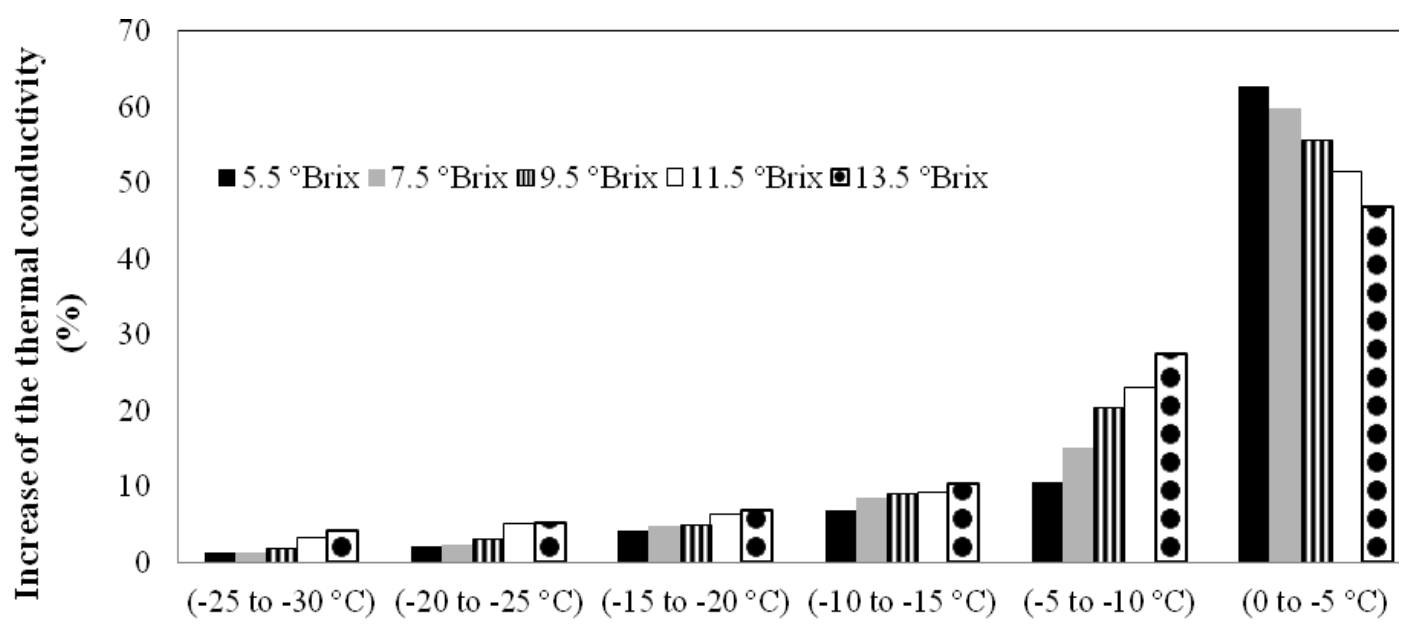

Temperature ranges $\left({ }^{\circ} \mathrm{C}\right)$

The behavior shown in Figure 7 indicates that for the temperature range of 0 to $-5^{\circ} \mathrm{C}$, pulp with a low concentration of solids $\left(5.5^{\circ} \mathrm{Brix}\right)$ had a higher percentage increase in thermal conductivity compared with more concentrated pulps. As for the rest of the temperature range, the percentage increase in the thermal conductivity is always higher for the more concentrated pulp. This can be justified by having a larger amount of liquid water available to freeze, thus increasing the thermal conductivity of the frozen pulp. This behavior can be compared with Figure 5. 
The water in the ice form is the food component that contributes most to the thermal conductivity value. Therefore, the dynamics of ice formation are similar to the dynamics of increased conductivity as a function of the temperature decrease.
Figure 8 shows the behavior of the thermal conductivity of the pulp when the temperatures are fixed.

The trend of the conductivity as a function of the solids concentration was linear. The equations obtained from the evaluation of conductivity versus concentration are presented in Table 6.

Figure 8. Behavior of the thermal conductivity of the pulps when the temperatures are fixed.

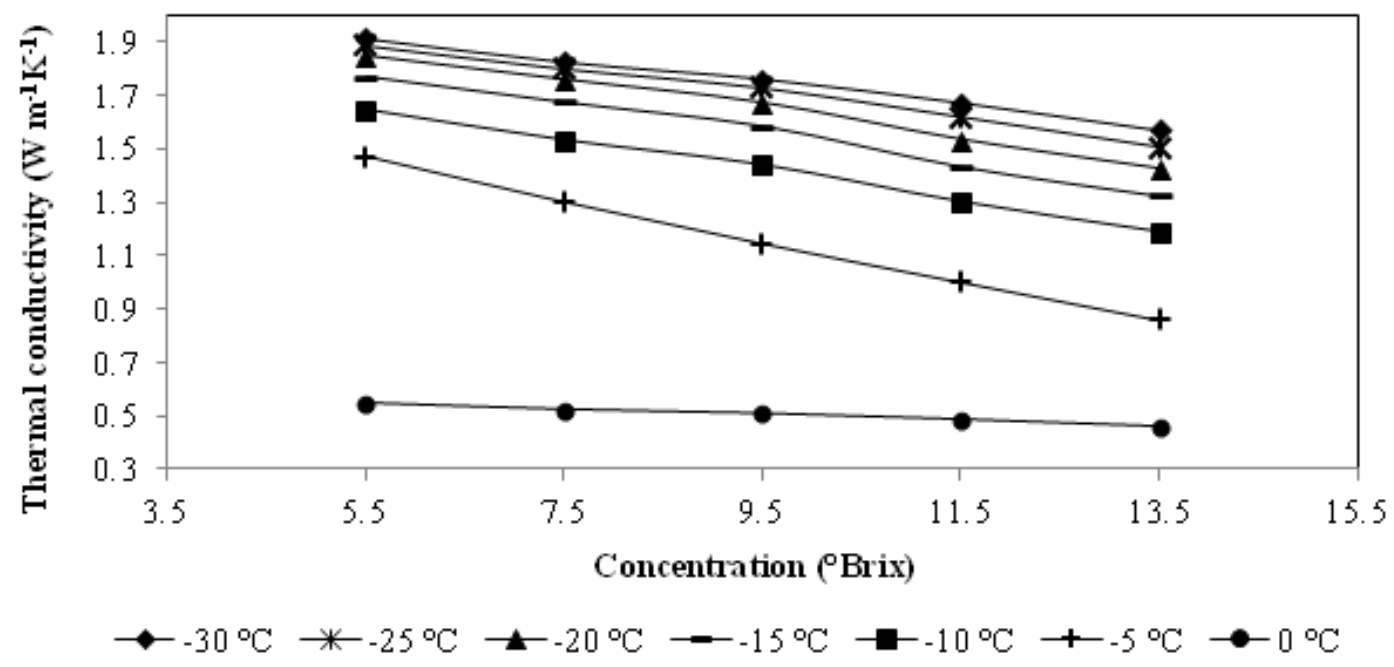

Table 6. Linear models adjusted for determining the thermal conductivity of the pulp in the concentration range from 5.5 to $13.5^{\circ}$ Brix.

\begin{tabular}{ccc}
\hline Temperature $\left({ }^{\circ} \mathrm{C}\right)$ & Equations $\left(5.5^{\circ}\right.$ Brix $\leq c \leq 13.5^{\circ}$ Brix $)$ & $\mathrm{R}^{2}$ \\
\hline-30 & $k=-0.041 c+2.144$ & 0.993 \\
-25 & $k=-0.047 c+2.158$ & 0.992 \\
-20 & $k=-0.053 c+2.155$ & 0.992 \\
-15 & $k=-0.056 c+2.092$ & 0.991 \\
-10 & $k=-0.057 c+1.965$ & 0.997 \\
-5 & $k=-0.075 c+1.876$ & 0.998 \\
0 & $k=-0.010 c+0.606$ & 0.992 \\
\hline
\end{tabular}

where: $k$ - thermal conductivity $\left(\mathrm{Wm}^{-1} \mathrm{~K}^{-1}\right) ; c-$ concentration of the acerola pulp ( $\left.{ }^{\circ} \mathrm{Brix}\right)$.

The evaluation of the thermal conductivity as a function of the solids concentration made it possible to adjust the simple linear mathematical models. This made it possible to directly obtain the thermal conductivity of the pulp without experimental evaluations, necessitating only a temperature data analysis and knowledge of the pulp concentration. 
Comparison of the experimental thermal conductivity obtained using the parallel, series and conductivity with that determined by structural Maxwell-Eucken (ME) theoretical models for the models $7.5^{\circ}$ Brix pulp at different temperatures. Figure 10

Figure 9 shows the thermal conductivity obtained experimentally and the thermal presents the percentage errors involved between the experimental and theoretical data.

Figure 9. Experimental thermal conductivity and theoretical values obtained using the series, parallel and MaxwellEucken (ME) models for the pulp with $7.5^{\circ}$ Brix.

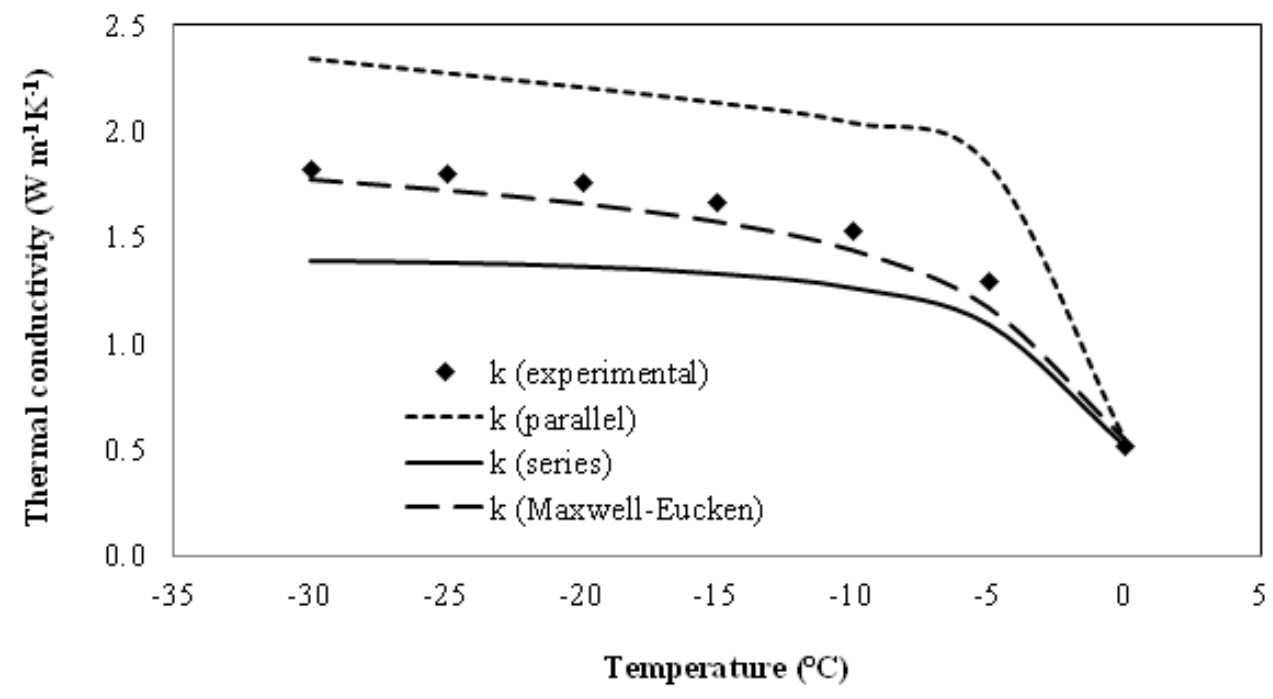

Figure 10. Evaluation of the error between the experimental thermal conductivity and the theoretical values obtained with the parallel, series and Maxwell-Eucken models for pulp with $7.5^{\circ}$ Brix.

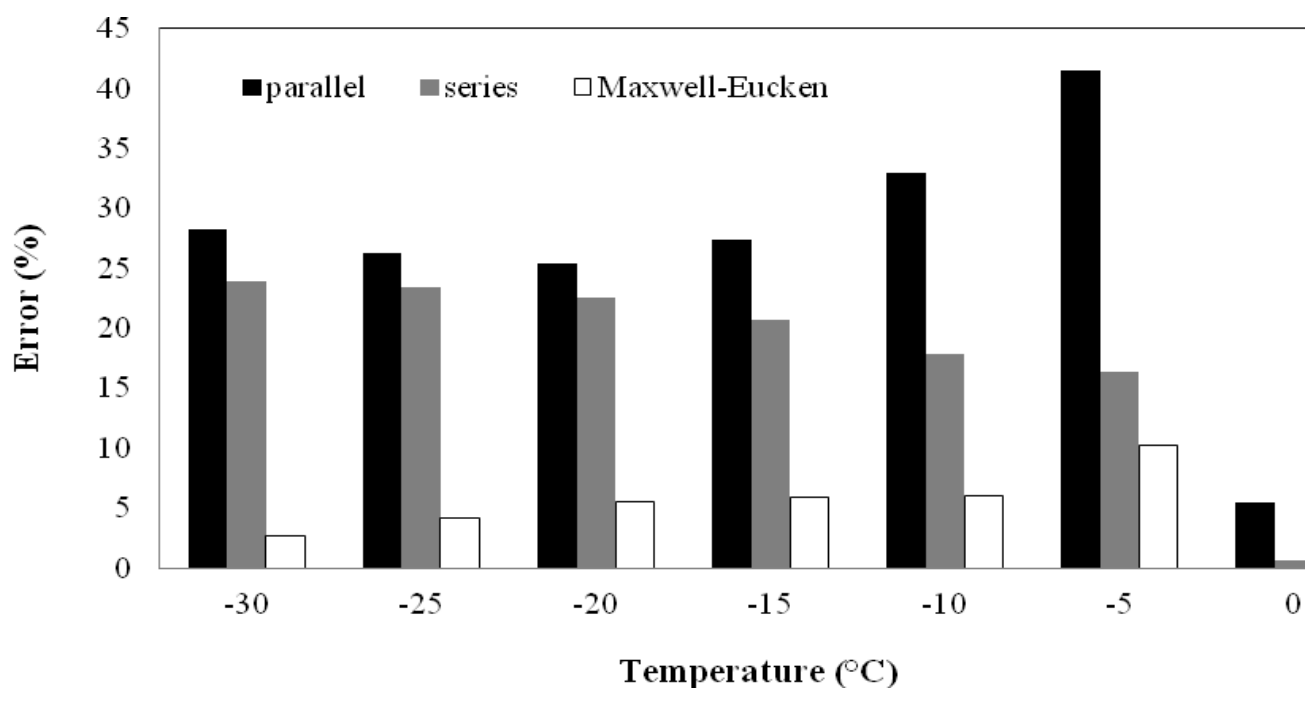


For pulp with $7.5^{\circ}$ Brix in the temperature range from -30 to $-5^{\circ} \mathrm{C}$, the maximum errors were found using the parallel model, and smaller errors occurred using the Maxwell-Eucken model. Second Miyawaki and Pongsawatmanit (1994), the selection of an appropriate heat transfer model is important for a mathematical analysis of the effective thermal conductivity of frozen food material and among the heat transfer models, the Maxwell-Eucken has been used for an analysis of the effective thermal conductivity of several products with best results. The best results obtained by the Maxwell-Eucken model were because this model is a combination of the other two and it considers that the heat transfer acts at the same time parallel and perpendicular to the phases. Therefore the Maxwell-Eucken model has intermediate resistance and shows best what actually occurs in a food.

At $0{ }^{\circ} \mathrm{C}$, the smallest error was observed for the Maxwell-Eucken model. According to Rao et al. (2005), the theoretical models sometimes fail because they are modeled on food in general, and the food structure influences its thermal conductivity. Foods that contain fiber exhibit different thermal conductivity behaviors depending on the direction of the fibers. Similarly, the porosity has a significant influence, and the freezing process can significantly alter porosity (RAO et al., 2005).

Thus, the experimental determination of the thermal conductivity becomes necessary to obtain accurate data, enabling the adjustment of specific models for each type of food.

\section{Conclusions}

From this study, it was found that the thermal conductivity is a thermophysical property dependent on the temperature and concentration. The ice fraction was largely responsible for the abrupt changes observed in the temperature range close to the initial freezing temperature. The conductivity increased with decreases in the temperature and soluble solids concentration, but the experimental data did not completely agree with the analyzed mathematical models (parallel, series and MaxwellEucken models).

The adjusted equations for direct evaluation of the thermal conductivity of the pulp provided greater accuracy than those obtained with the theoretical models. They are important for future engineering calculations involving heat transfer because they will facilitate the optimization of industrial processes.

\section{Acknowledgements}

The authors wish to thank the Fundação de Amparo à Pesquisa do Estado de Minas Gerais (FAPEMIG- Brazil), Conselho Nacional de Desenvolvimento Científico e Tecnológico ( $\mathrm{CNPq}$ - Brazil), and Coordenação de Aperfeiçoamento de Pessoal de Nível Superior (CAPES - Brazil) for financial support for this research.

\section{Nomenclature}

\begin{tabular}{llc}
$L$ & Latent heat of fusion & \multicolumn{1}{c}{$\mathrm{kJ} \mathrm{kg}^{-1}$} \\
$M$ & Molecular weight & $\mathrm{kg} \mathrm{kg}^{-1} \mathrm{~mol}^{-1}$ \\
$\mathrm{R}$ & Universal gas constant & $\mathrm{kJ} \mathrm{kg}^{-1} \mathrm{~mol}^{-1} \mathrm{~K}^{-1}$ \\
$R$ & Electrical resistance & $\Omega \mathrm{m}^{-1}$ \\
$T$ & Temperature & ${ }^{\circ} \mathrm{C}$ or K \\
$X^{v}$ & Volumetric fraction & - \\
$X$ & Molar fraction & - \\
$c$ & Concentration & ${ }^{\circ} \mathrm{Brix}$ \\
$f$ & Correction factor & - \\
$i$ & Electrical current & $\mathrm{A}$ \\
$k$ & Thermal conductivity & $\mathrm{W} \mathrm{m} \mathrm{K}^{-1}$ \\
$m$ & Slope of the straight line & - \\
$\mathrm{m}$ & Mass & $\mathrm{kg}$ \\
$q$ & Power per meter & $\mathrm{W} \mathrm{m}{ }^{-1}$ \\
$t$ & Time & $\mathrm{S}$
\end{tabular}




$\begin{array}{lll}x & \text { Mass fraction } & - \\ \rho & \text { Density } & \mathrm{kg} \mathrm{m}^{-3}\end{array}$

$\begin{array}{ll}\text { Subscripts } \\ c & \text { Continuous } \\ d & \text { Disperse } \\ i & \text { Pure component } \\ \mathrm{f} & \text { Initial freezing } \\ \mathrm{f} S & \text { Initial freezing of the sample } \\ \mathrm{f} w & \text { Initial freezing of water } \\ m e & \text { Maxwell-Eucken } \\ n & \text { Number of components } \\ o & \text { Initial } \\ p a & \text { Parallel } \\ s & \text { Solids } \\ s e & \text { Series } \\ w & \text { Water } \\ w o & \text { Unfrozen water }\end{array}$

\section{References}

AMERICAN SOCIETY OF HEATING, REFRIGERATION AND AIR-CONDITIONING ENGINEERS - ASHRAE. Handbook Refrigeration. Atlanta: Refrigeration and Air-conditioning Engineers, 2002.

ASSOCIATION OF OFFICIAL ANALYTICAL CHEMISTS - AOAC. Official Methods of Analysis. $16^{\text {th }}$ ed. Arlington: AOAC, 1996.

AZOUBEL, P. M.; CIPRIANI, D. C.; EL-AOUAR, A. A.; ANTONIO, G. C.; MURR, F. E. X. Effect of concentration on the physical properties of cashew juice. Journal of Food Engineering, Essex, v. 66, n. 4, p. 413417, 2005.

BECKER, B. R.; FRICKE, B. A. Food thermophysical property models. International Communications in Heat and Mass Transfer, New York, v. 26, n. 5, p. 627-636, 1999.
BROCK, J.; NOGUEIRA, M. R.; ZAKRZEVSKI, C.; CORAZZA, F. C.; CORAZZA, M. L.; OLIVEIRA, J. V. Determinação experimental da viscosidade e condutividade térmica de óleos vegetais. Ciência e Tecnologia de Alimentos, Campinas, v. 28, n. 3, p. 564570, 2008.

CARSON, J. K. Review of effective thermal conductivity models for food. International Journal of Refrigeration, Surrey, v. 29, n. 6, p. 958-967, 2006.

HELDMAN, D. R. Food properties during freezing. Food Technology, Chicago, v. 36, n. 2, p. 92-96, 1982.

HELDMAN, D. R.; LUND, D. B. Handbook of food engineering. NewYork: Marcel Dekker, 1992.

INSTITUTO ADOLFO LUTZ - IAL. Normas analíticas do Instituto Adolfo Lutz: métodos físico-químicos para análise de alimentos. 4. ed. São Paulo: Instituto Adolfo Lutz, 2008. 1020 p.

MANICA, I.; ICUMA, I. M.; FIORAVANÇO, J. C.; PAIVA, J. R.; PAIVA, M. C.; JUNQUEIRA, N. T. V. Acerola: tecnologia de produção, pós-colheita, congelamento, exportação, mercados. Porto Alegre: Cinco Continentes, 2003. 397 p.

MERCALI, G. D.; SARKIS, J. R.; JAESCHKE, D. P.; TESSARO, I. C.; MARCZAK, L. D. F. Physical properties of acerola and blueberry pulps. Journal of Food Engineering, Essex, v. 106, n. 4, p. 283-289, 2011.

MIYAWAKI,O.;PONGSAWATMANIT,R. Mathematical analysis of the effective thermal conductivity of food materials in the frozen state. Bioscience, Biotechnology Biochemistry, Tokyo, v. 58, n. 7, p. 1222-1225, 1994.

PEREIRA, C. G.; RESENDE, J. V.; PEREIRA, G. G.; GIAROLA, T. M. O.; PRADO, M. E. T. Thermal conductivity measurements and predictive models for frozen guava and passion fruit pulps. International Journal of Food Properties, Philadelphia, v. 16, n. 4, p. 778-789, 2013.

RAHMAN, M. S. Food properties handbook. $2^{\text {th }}$ ed. Boca Raton: CRC Press, 2009. 867 p.

RAO, M. A.; RIZVI, S. S. H.; DATTA, A. K. Engineering properties of foods. $3^{\text {th }}$ ed. Boca Raton: Taylor and Francis, 2005. $738 \mathrm{p}$.

RENAUD, T.; BRIERY, P.; ANDRIEU, J.; LAURENT, M. Thermal Properties of food materials in the frozen state. Journal of Food Engineering, Essex, v. 15, n. 2, p. 83-97, 1992. 
RENO, J.; RESENDE, J. V.; PERES, A. P.; GIAROLA, T. M. O.; PRADO, M. E. T. Heat transfer and energy consumption in the freezing of guava pulp in large containers. Aplied Thermal Engineering, Oxford, v. 31, n. 4, p. 545-555, 2011.

RITZINGER, R.; KOBAYASHI, A. K.; OLIVEIRA, J. R. P. A cultura da aceroleira. Cruz das Almas: Embrapa Mandioca e Fruticultura, 2003. 198 p. 